\title{
'Sasanian' silver plate from al-Ṣabāḥ Collection in light of aesthetic features of Sasanian toreutics
}

\author{
https://doi.org/10.34739/his.2019.08.04
}

\begin{abstract}
Recently published silver plate from al-Șabāh Collection, of unknown provenance, has been firmly attributed as Sasanian. In fact, technically, it is related to the Sasanian silverwork however aesthetic examination allows to raise the doubts whether it is genuine. The plate must be compared not only with central-Sasanian artworks but all ancient 'Oriental silver', including pieces attributed as Hephtalite or Sogdian. The design of the plate does not have any relation with any of the known examples of late antique oriental toreutics. Central scene of heroic combat with powerful beast or beasts has never been surrounded with the ring containing other hunting scenes is unknown as well. The disbalanced decorum is even more clear when we remind that the central scene shows hunting on foot and the marginal ones - mounted. The details of fixed aesthetic elements - position of personages, beasts, weapons do not belong to Sasanian canon. The unique nature of the plate might result from many factors but the combination of unknown provenance and lack of relation to legitimate Sasanian canon require utmost cautiousness towards the object.
\end{abstract}

Key words: Sasanian silver, al-Ṣabāḥ Collection, toreutics, Iran, Art, Metalwork

\section{Introduction}

'Recently, some academic authorities have maintained that no scholar should study antiquities that lack scientific proof of provenance [...]. In a more perfect world, governments would protect sites where antiquities had been excavated, and individual finders works of ancient art would be paid reasonable fees to turn them over to governmental authorities, as the case of the United Kingdom. Obviously, in many war-torn and poverty-stricken regions of the world today this is not possible'.

This brief apology of illegal art trade or antiquity trafficking is an excerpt from Martha Carter's Preface to Arts of Hellenized East. Precious Metalwork and Gems of the Pre-Islamic Era, a catalogue of a part of al-Șabạ̄ Collection from Kuwait. Apart

\footnotetext{
* ORCID iD 0000-0002-8119-5449. patryk.skupniewicz@gmail.com; Institute of History and International Relations, Faculty of Humanities. The results of the research carried out under the research theme No. 133/15/MN were financed from the science grant granted by the Ministry of Science and Higher Education.
}

${ }^{1}$ CARTER 2015: 12 . 
from ethical issues which may raise from such a statement, this sentence carries serious implications for the methodology of ancient art history. If the finds 'that lack scientific proof of provenance' are to be accepted their genuineness must be stated beyond any doubt. This can be confirmed if the objects in question follow known and acknowledged patterns, principles or formulae of specific corpus. It is more complicated when the objects obtained from the site robbers and smugglers vary in various points from known examples and therefore were to enrich our knowledge about the features of art under discussion. Accepting the objects which bring iconographic or formal novelties should be much more measured than the ones simply confirming current state of knowledge. In my opinion this is the case of the plate published in the quoted catalogue under catalogue number 82 and earlier in Splendors of the Ancient East: Antiquities from The al-Sabah Collection ${ }^{2}$ [Fig. 1]. This plate was attributed as Sasanian and dated 'c. 300' however no discussion over the differences in iconography, structure and composition of the image was provided. The details of the plate are executed in correct early-Sasanian style, the treatment of almost all elements is perfectly in line with Sasanian techniques ${ }^{3}$. It is inscribed in Pahlavi with ownership and weight declaration (which definitely supports its genuineness ${ }^{4}$ ), however the visual language of the plate, its composition, layouts of the scenes rise questions. It is not impossible that such a variance could occur, as the assemblage of the recognized comparative material is rather limited, therefore it is justified to expect some regional traditions. On the other hand, regional school may become an easy excuse for the inconsistencies. New elements which change the perspective on Sasanian art must have clear identifiable provenance in order to be accepted ${ }^{5}$. All differences between illegal founds and known visual principles of Sasanian art speak against genuineness of the founds at least until methodological excavations confirm them.

Such a reluctance to acknowledge new traits may raise the question of originality and individual style in Sasanian art. It must be borne in mind that the toreutics is part of applied arts and most definitely follows the principles of existing visual language of the era, for sure being the least experimental form of art. In fact, silverwares are the objects of luxury and in traditional terminology they belong to craftsmanship rather than art however such a distinction was probably unknown in Sasanian Iran and the artisans of all sorts created A social group of rather low status ${ }^{6}$. The depictions, in order to be formally legible, had to follow commonly known

\footnotetext{
${ }^{2}$ CARTER 2015: 292-299; FREEMAN 2013: 172-173.

${ }^{3}$ HARPER, MEYERS 1981: 127-133; MEYERS 1981: 147-158.

${ }^{4}$ SKJAERVØ 2013: 299.

${ }^{5}$ As is the case with the silver plate discovered by the Czech expedition in Mes Aynak, see: MLEZIVA 2016: 98-105.

${ }^{6}$ LUKONIN 1983: 632-633; KARIMIAN 2008: 102-105; OLBRYCHT 2010: 263-264; KOLESNIKOV 2012: 391-399; MARSHAK 1986: 255-263; MARSHAK 2017: 266-270.
} 
and recognizable criteria ${ }^{7}$. This phenomenon reinforced the conservatism of the Sasanian art and stemmed the survival of the iconographic elements over centuries even long after the fall of the empire. The longue durée and the limited number of the fixed formulae of Sasanian art indicates their quasi-canonical nature ${ }^{8}$. This indicates that the violation of the visual principles in Sasanian art is rather unlikely within the frames of current knowledge ${ }^{9}$. Current paper aims in highlighting the discrepancies between the plate from al-Sabāh collection and the decoration of the Sasanian or Sasanian-related toreutics.

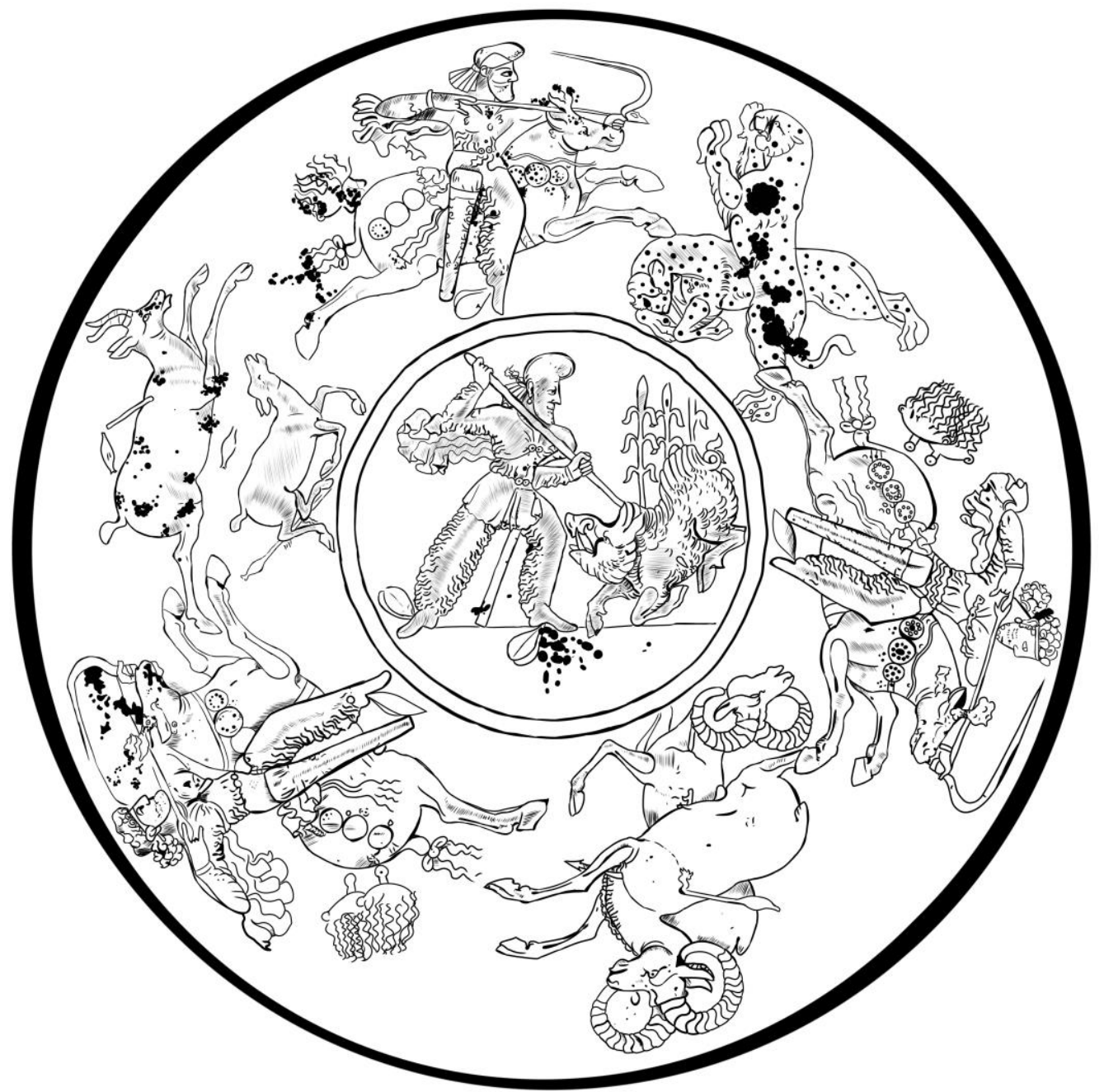

Fig. 1. The plate from al-Șabāḥ Collection (drawing by Eleonora Skupniewicz)

\footnotetext{
${ }^{7}$ GRABAR 1967: 44, uses even the term Kunstindustrie to describe Sasanian silverware manufature.

8 GRABAR 1967: 34-36, 44, 82-84; GRAY 1991; CIAFALONI, DELLA ROCA DE CANDAL 201; HARPER 2000; HARPER 2008: 115-163; MARSHAK 1986: 255-262, 276-279; MARSHAK 2012: 283290.

${ }^{9}$ Specifically in the light of repetitive nature of the used patterns, GRABAR 1967: 44.
} 


\section{The plate from al-Ṣabāḥ Collection}

The plate is made of silver. Its shape is almost round with diameter 31,4-31,7 $\mathrm{cm}$. the body of the plate is placed on the round foot which is 10,4-10,6 cm in diameter. The plate is $5 \mathrm{~cm}$ high with foot covering $0,9 \mathrm{~cm}$ of that dimension. The weight of the object is $1,797 \mathrm{~kg}$. The plate has the ownership inscription stating its weight of 115 staters.

The interior of the plate is decorated with figures of hunters and prey in low relief achieved though inserting pre-worked elements in the holes made in the internal surface of the vessel. The decoration is divided into round, separated panel with a hunting scene with a hunter on foot, the scene is placed within the pronounced circle at the center of the bottom of the vessel. On the wall or brim of the plate there is the sequence of three mounted hunts on the wall.

The central scene consists of the main personage standing on the left, with his left contour marking the vertical axis of the scene, in the right half of the scene a fallen boar was depicted with three canes behind it. Both feet of the man, boar's knee and one of the hooves are placed on the horizontal line constituting ground level. The animal is shown with its body placed somehow diagonally with back over the front. Only boar's head rises up. Hunter's head is shown in the right profile, wide shoulders and narrow waist are depicted frontally, the legs are slightly spread, his left leg is turned towards right and slightly bent, right leg is stretched backwards i.e. towards left. He wears the tiara with rounded top falling to the front. His hair is shown in series of four thick locks falling on his neck. He is wearing pointed beard and characteristic wavy moustache. A pearl-earring hangs from his ear. His torso is covered with a short tunic reaching his mid-thigh and a sleeved coat fastened in the center of his chest, vigorously floating behind his back. His legs are covered by baggy trouser or leggings. He has almond-shaped objects, probably tassels affixed to his shoes. Between the legs there is a sword sheath while the hilt of the sword, with long cross-guard and no-pommel, is placed over the left thigh of the personage. The man is holding a spear with the shaft passing diagonally across his chest and hitting the boar over its head, the tip of the spear transfixes the beast and comes out behind its left right hind. Butt-end of the shaft is held in the hunter's right hand while the left hand holds it on the shoulder level.

The external register consists of three riders with bows, all turned right, and their prey. All riders are shown on the mounts depicted in 'flying gallop' with stretched legs and 'ballerina' feet and large quivers decorated with floral motives hanging from the hips. They all are drawing the bows and pointing the arrows towards quarry. All men are wearing tunics and cloaks fastened at the center of the chest, floating behind their backs. Their legs are covered with baggy trousers or leggings. The almond-shaped 'tassels' are affixed to their shoes. They sit in 'horned' saddles indicated by the front 'horns' bent over their thighs. All the horses have trimmed manes with buns over 
foreheads, ribbons floating from the temples and harness straps covered with series of the round phalerae. The reigns are depicted in wavy lines affixed to long shanks. There are double tassels flying behind the rumps and tails tied carefully in bows. The riders vary with headgear and prey. The rider directly above the personage from the central panel wears similar headgear and coiffure to the central personage. He hunts two leopards placed in front of him in an X-shape layout, with one jumping towards the hunter with a broken arrow stuck in its chest with the pieces of the arrow flying between the hunter and the prey. The other leopard, already dead, with arrow in its chest, is shown stretched diagonally with the head down and paws in a posture resembling the forelegs of the boar from the central scene. The scene placed directly over central depiction, according to its vertical dimension, constitutes the main axis of entire plate. The other two horsemen have curly coiffures with a ball-shaped tail at the back of their head and shorter beards however with the same wavy moustaches. They also wear narrow diadems or bands round their heads running at the line of the forehead, the temples and over the ears. The rider to the right hunts rams, one of them is running away (if flying gallop) from the rider however already hit with an arrow behind shoulder plate, the other animal is shown dead in similar way as the boar from the central scene and the leopard killed by the first rider. The last rider chases an antelope depicted in flying gallop, with a broken arrow stuck in its back while the young antelope is shown right below the body of the main prey.

\section{General layout}

The layout of the al-Ṣabāh collection plate under discussion does not find any direct match among known Sasanian silver or related arts. The vast majority of the hunt depictions in Sasanian toreutics avoids dividing pictorial field and the scene with victorious hunter with royal (or so-called princely) attributes shown in the act of slaying the prey, occupy entire round format of interior of a plate ${ }^{10}$. Although there are examples of the hunting scenes placed within medallions or even no-separated otherwise than by decorative motifs or free space but they are never located on the plates, being a part of external decoration of bowls or vases, in most of the cases they seem to be associated with other motifs and they do not highlight the very act of a hero killing beasts (Cleveland Museum of Arts bowl from J.H. Wade collection ${ }^{11}$, two vases from National Collection in Teheran [Fig. 2] ${ }^{12}$, vase from Yuldus ${ }^{13}$, bowl

\footnotetext{
${ }^{10}$ HARPER, MEYERS 1981: 42-47, 197-199; TREVER, LUKONIN 1987: 54-63; SKUPNIEWICZ 2015: 186-188.

${ }^{11}$ HARPER 1978: 53-54; TREVER, LUKONIN 1987: 88.

12 HARPER 1978: 51-52, 71-73; ROSEN-AYALON 1991: 66-67; TREVER, LUKONIN 1987: 94; SKUPNIEWICZ 2009: 52-54.

${ }^{13}$ SHLYAKHOVA 1977: 289-291; MARSHAK 1986: No 192; MARSHAK 2017, Fig. 192; HARPER 2008: 128-129, 150; SKUPNIEWICZ 2009: 60-61.
} 
from Terek in Hermitage ${ }^{14}$, vase from Hermitage ${ }^{15}$ ). On top of that all known examples come from the late Sasanian or post-Sasanian period they clearly constitute different type of imagery, another genre than the 'classical' or 'canonical', 'royal' or 'princely' Sasanian silver plates. Among examples of Sasanian silver there are only few examples of locating the hunt scene within a medallion and it never happens on the plate but different types of vessels ${ }^{16}$.

The hunting scenes are usually a subject sufficient for itself, they rarely share the pictorial field. The examples come from late and post-Sasanian period. On the plate excavated in Strelka, now exhibited in Hermitage [Inv. No. S-520] one can see the pictorial filed divided into two parts: upper showing enthroned king with some members of his court and smaller lower with the hunting scene ${ }^{17}$. This division is different from the one presented by the plate under discussion and the scene itself belongs to another type than al-Ṣabāh collection piece. Strelka plate is firmly dated for late or post-Sasanian period. It can be therefore firmly stated that in none of the known Sasanian plates, the hunt scene was placed in a central medallion of the interior of the bowl. There is a bowl from Freer Gallery of Art [Inv. No. S1987.143] which contains a schematic scene of a hero stabbing a rampart lion 'crudely engraved' or rather scratched in the center of its bottom with majority of the surface left plain, however the bowl is elliptical in shape, the scene is not placed within any frame, there are no scenes surrounding the central depiction, the technique of manufacture and artistic quality are different and again it is dated to late or post-Sasanian period ${ }^{18}$. The scene might have been added even after the vessel was manufactured.

The scenes placed running around a round medallion placed in the center of the circle are quite common idea of distribution of decoration on the vessels, usually they are associated with the Eastern part of 'Greater Iran'. They include: KushanoSasanian plate from Punjab, exhibited in British Museum [Inv. No. 124093], with central circle divided into two registers, each containing separate enthronement scene and other depictions running around the brim ${ }^{19}$; the plate from Hermitage, found in Nizhne Shahrovka [Inv. No. S-74], with a goddess on the lion with an attendant in the central medallion, surrounded with the silhouettes of armed foot-men placed in sequence with the medallions containing protomes of wild animals ${ }^{20}$. This plate seems related to the group of the vessels with a central medallion surrounded by other

\footnotetext{
${ }^{14}$ TREVER, LUKONIN 1987: 115, Pl. 75-76; HARPER 2008: 134-135, 154; SKUPNIEWICZ 2009: 5255 .

${ }^{15}$ TREVER, LUKONIN 1987: 107, Pl. 1; SKUPNIEWICZ 2009: 52-54.

16 HARPER 1978: 51-52, 71-73; ROSEN-AYALON 1991: 66-67; TREVER, LUKONIN 1987: 94; SKUPNIEWICZ 2009: 52-54, 60-61; SHLYAKHOVA 1977: 289-291; MARSHAK 1986: No 192; HARPER 2008: 128-129, 150.

${ }^{17}$ HARPER, MEYERS 1981: 67-68, Pl.19; TREVER, LUKONIN 1987: 109.

${ }^{18}$ GUNTER, JETT 1992: 177-179.

${ }^{19}$ HARPER 1979: 53, Fig. VIII; HARPER, MEYERS 1981: 108-110 (Fig. 35); TREVER, LUKONIN 1987: 70; MARSHAK 1986: 263-264, Pl. 96; MARSHAK 2017: 277-280, Pl. 96-96A.

${ }^{20}$ TREVER, LUKONIN 1987: 107, Figs, 1-5; MARSHAK 1986: Pl. 97; MARSHAK 2017, Pl. 97.
} 
medallions, usually containing busts of personages. The bowls from Hermitage collection found in Perm Region and Kustanai [Inv. No. S48; S57] ${ }^{21}$ or the bowl associated with Greco-Bactrian milieu, from Freer Art Gallery (the scenes include a depiction of a man spearing a bear ${ }^{22}$; stylistically and thematically related to it bowls from Hermitage ${ }^{23}$, the bowl found in Chilek near Samarkand being identified as Hephtalite $^{24}$. One more 'Late Bactrian Bowl' with central medallions containing a rosette was found in Kvashchileva in Perm Region has four sections containing depictions of the horses on the outer wall ${ }^{25}$. Also the bowl from Hermitage collection decorated with four faces around outer wall has the central medallion with a rosette ${ }^{26}$. Among the vessels containing the sequence of the scenes on the outer wall and having bottom decorated with a medallion with figurative decoration one may list the bowl from Cleveland Museum of Arts [Fig. 3] with various leisure scenes (they seem to relate to so-called Dionisiac imagery in Sasanian art however they include a bear hunt on foot inside a Paradeisos which is clearly indicated by the net hanging by the side of the bear $)^{27}$. Somehow related to the latter seem a bowl from Freer Art Gallery [Inv. No. S1987.105] with a bust placed within the bottom/central medallion. Except for Nizhne Shahrovka plate and the bowl from Cleveland Museum of Arts they are by no means connected with hunt. Even the latter ones depict very different form of hunt from 'royal' silver. On Nizhne Shahrovka the idea of fighting the beasts is merely suggested by the sequence of armed men and animal protomes, in Freer Gallery bowl the hunt is diminished to one of activities. It is directly derived from Roman mosaic and therefore distant from Sasanian fighting with the beasts imagery. None can be attributed clearly as Sasanian.

The only depiction which combines the central medallion with the mounted hunting scenes running along the outer circle is the one obtained in Punjab, now in British Museum [Inv. No. OA 1963-12-10.1], again identified as Hephtalite, however it is decorated on outer, not inner surface and does not contain hunting scene within the central medallion ${ }^{28}$. This is highly logical as in the situation when decoration runs on external walls the central circle is the element least visible. It might be noted here that bowl from Terek, dated as late-post Sasanian contains 'central medallion' with a 'senmurv' and has depictions of hunters on foot separated from their prey with the schematic trees which create four, separete panels. Another post-Bactrian or Hephtalite bowl, found in Vereino in Perm region, now in Hermitage, also shows

\footnotetext{
${ }^{21}$ TREVER, LUKONIN 1987: 115; Figs. 26-27.

${ }^{22}$ GUNTER, JETT 1992: 148-156.

${ }^{23}$ TREVER 1940: 71-81, Pls. 15-21.

${ }^{24}$ MARSHAK, KHIKIS 1969; MARSHAK 1986: 29-38; MARSHAK 2017: 72-82.

${ }^{25}$ TREVER 1940: 90-92, Pls. 25-26.

${ }^{26}$ TREVER 1940: 93-96, Pl. 27.

${ }^{27}$ HARPER 1978: 53-54; TREVER, LUKONIN 1986: 88; SKUPNIEWICZ 2008: 54-55.

${ }^{28}$ HARPER, MEYERS 1981: 130-131, Fig. 44; NIKONOROV 1997.
} 
the sequence of lion and tiger hunt scenes on its outside ${ }^{29}$. Instead of central medallion it contains a rosette. The last object that might serve as an analogy for the general composition of al-Șabāh Collection plate is peculiar bowl from David Collection in Copenhagen [Inv. No. 2.1984] which contains the mounted hunting scenes in Sasanian style on its exterior, it is dated to $4^{\text {th }}$ century ${ }^{30}$.

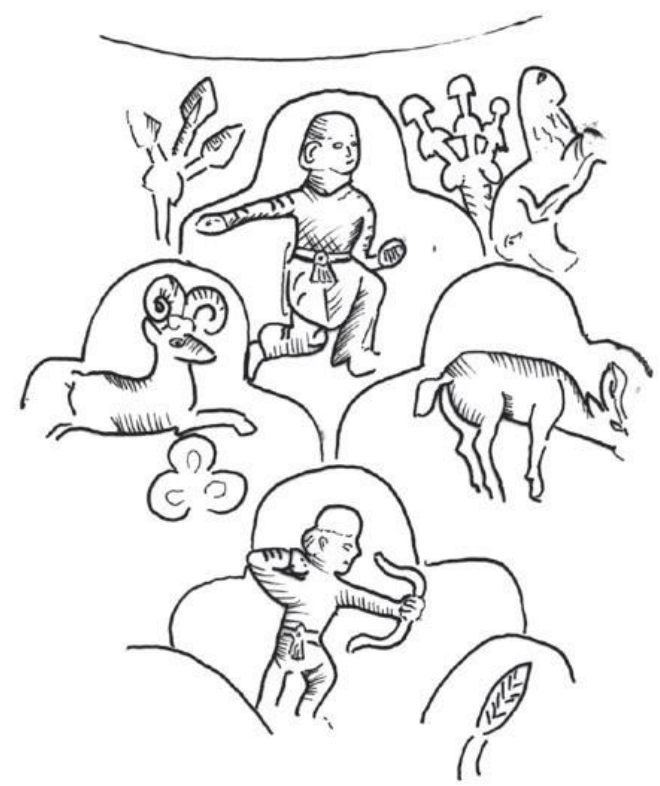

Fig. 2. Hunters from Teheran Museum vase (drawing by Patryk Skupniewicz)

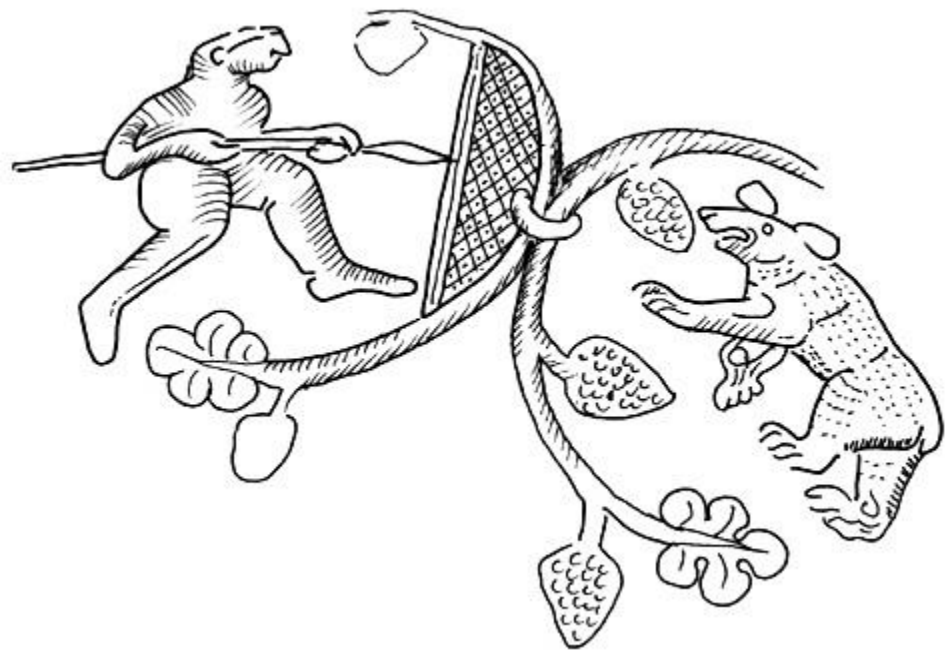

Fig. 3. The bowl from Cleveland Museum of Arts (drawing by Patryk Skupniewicz)

\footnotetext{
${ }^{29}$ TREVER 1940: 87-90, Pl. 22-24; NIKONOROV 1997.

${ }^{30}$ HARPER 2006: 126, 146, Fig. 66.
} 
It is clear that al-Ṣabāh Collection plate cannot be fully matched with any of the composition principles from Sasanian or post-Hellenistic, Central Asian arts. Placing the scene where the main personage is shown fighting a powerful, lifethreatening beast within a medallion and therefore diluting its heroic expression has never been practiced on any of the Sasanian silver plates. The very practice of depicting hunt in medallions or separated pictorial fields started in late or even postSasanian period and even then, did not become common. It is not attested in earlier imagery. Placing of the main scene in a medallion brimmed with some outer scenes finds its reference in the examples of Kushano-Sasanian plates and within purely Sasanian tradition it may be a result of an evolution of compositions consisting from medallions. The problem is, that the medallions creating external row of depictions remained in fashion and were even transferred to the style attributed to Hephtalites, also in the late Sasanian period the medallions seem rather replaced by the arcades, so the undivided sequence of scenes surrounding central medallion of crucial importance would be an phenomenon short-lived and geographically limited. Another surprising feature of the composition of the al-Șabā Collection plate is that the mounted hunting scenes create a margin for a scene of combat with the beast on foot, this way the importance seems reversed. The size of the prey on the outer rim is bigger than the main personage in central part. It must be also mentioned that the sequences of scenes of mounted hunt related to the aesthetics of Sasanian toreutics are all depicted on external part of the vessel and none of them originates from early Sasanian milieu. The composition of the plate from al-Ṣabā Collection in comparison to the corpus of Sasanian toreutics seems odd and not fitting the decorum of the era. Even with some handicap given for sake of allegedly East Iranian origin there are no direct and clear references found.

\section{Main scene}

The main scene shows a combat on foot between a man and a boar. This theme is not exceptional in Sasanian toreutics. Although not as common as different form of mounted hunt there are several representations of this type within 'royal' or 'princely' iconography as well as examples of non-'royal' depictions ${ }^{31}$. The formula applied in the central scene does not match any of the formerly know Sasanian examples, except for the plate published in the same catalogue, attributed as Parthian.

Among the scenes of foot combat with the beasts which belong or relate to the 'royal' group where a spear is employed (there are examples of depictions of personages on foot fighting the animals or hunting with sword, bow or lasso), the dominant or the basic one shows the hunter standing upright or slightly bent towards right where the prey, stretched vertically is placed. The right contour of

${ }^{31}$ SKUPNIEWICZ 2009: 50-56. 
the hunter's silhouette marks the vertical axis of the composition. The shaft of the weapon is held with both hands at the hips level. As the examples one can list the plate from Metropolitan Museum of Art with Yazdegerd I slaying deer [Fig. 4] $]^{32}$, plate with Šāpūr II fighting bears from Shokagukan collection [Fig. 5] $]^{33}$, seal impression from M. Foroughi with a personage spearing a bear [Fig. 6] $]^{34}$. This layout corresponds with some formulae of the mounted hunt however the way the spear is held reminds the scenes of cavalry combat and less idealized non-'royal' scenes which on one hand seem more realistic on the other clearly follow Roman examples however it must be admitted that the scenes of hunt on foot with a spear appeared in Achaemenid small art and Achaemenid and Hellenistic Anatolian art ${ }^{35}$. The latter type can be exemplified with the plate from Nizhne Shahrovka, the bowl from Terek, the bowl from Cleveland Museum of Arts and the vase from National Collection in Teheran ${ }^{36}$. There are two examples of depicting the personages with the shafts held horizontally at the shoulder level: a scene of the bear hunt on East Iranian bowl from Freer Gallery of $\mathrm{Art}^{37}$ and the plate from Seattle Art Museum[Fig. 7$]^{38}$, the object that rises doubts whether it is genuine. The separate group within the depictions on silver plates of the fighting the beasts on foot with the spear is constituted by two plates: from Shelby and White Collection [Fig. 8] and from the tomb of Feng Hetu [Fig. 9] ${ }^{39}$. Both depict main personage standing upright on one leg in the center, spearing a boar protome on the right while the right leg of the personage is bent and foot rests on the boar head on the left. On the plate from the tomb of Feng Hetu there is a third boar protome in the lower right. The shaft is held in standard way i.e. on the level of the hips. This type must have been associated with a narrative topos which has not lasted until our times. No depiction of the hunting on foot shows the lance held diagonally across the chest except for 'Parthian' plate from al-Șabāh collection, where a personage in Parthian grab spears a humped bull ${ }^{40}$. Some Achaemenid seals provide examples of hunters performing single-handed downwards thrusts from above head (one from Kish shows even double handed thrust) they do not cross the torso of the hunter ${ }^{41}$. Among older art the ivory plaques representing various workshops of Assyrian imperial art show a personage killing the griffons with the spear crossing his chest diagonally ${ }^{42}$.

\footnotetext{
${ }^{32}$ GRABAR 1967: 77, 98, Pl. 10; HARPER, MEYERS 1981: 63-64, 217, Pl.19; SKUPNIEWICZ 2009: 51-52, Fig. 3.

${ }^{33}$ TANABE 2001: 181-182, Pl. II; SKUPNIEWICZ 2009: 51-52, Fig. 4.

${ }^{34}$ GYSELEN 1997: I-II; SKUPNIEWICZ 2009: 52-53, Fig. 6; RITTER 2010: 90-91, 236, Tab. X.

${ }^{35}$ BOARDMAN 2000: 161, 172; RITTER 2010: 198-199; FRANCFORT 2002.

${ }^{36}$ SKUPNIEWICZ 2009: 52-56.

${ }^{37}$ GUNTER, JETT 1992: 148-154; SKUPNIEWICZ 2009: 54, 57, Fig. 13.

${ }^{38}$ GRABAR 1967: 49-51, 77, 97, Pl. 37; SKUPNIEWICZ 2009, 52-53, Fig. 5.

${ }^{39}$ HARPER 1990: 51-61; HARPER 2005: 152-153; HARPER 2006: 123-125, 148, Pl. 68-69; HARPER 2008: 81; MARSHAK 2005: 51; SKUPNIEWICZ 2009: 50-51.

${ }^{40}$ CARTER 2015: 284-287.

${ }^{41}$ BOARDMAN 2000; FRANCFORT 2002.

${ }^{42}$ HERRMANN 2017: 71, Fig. 76, 88, 101, 110, 160, 139, 185, 203, in connection with late Bronze Age Cypriotic ivory handle: 70, Fig. 75.
} 


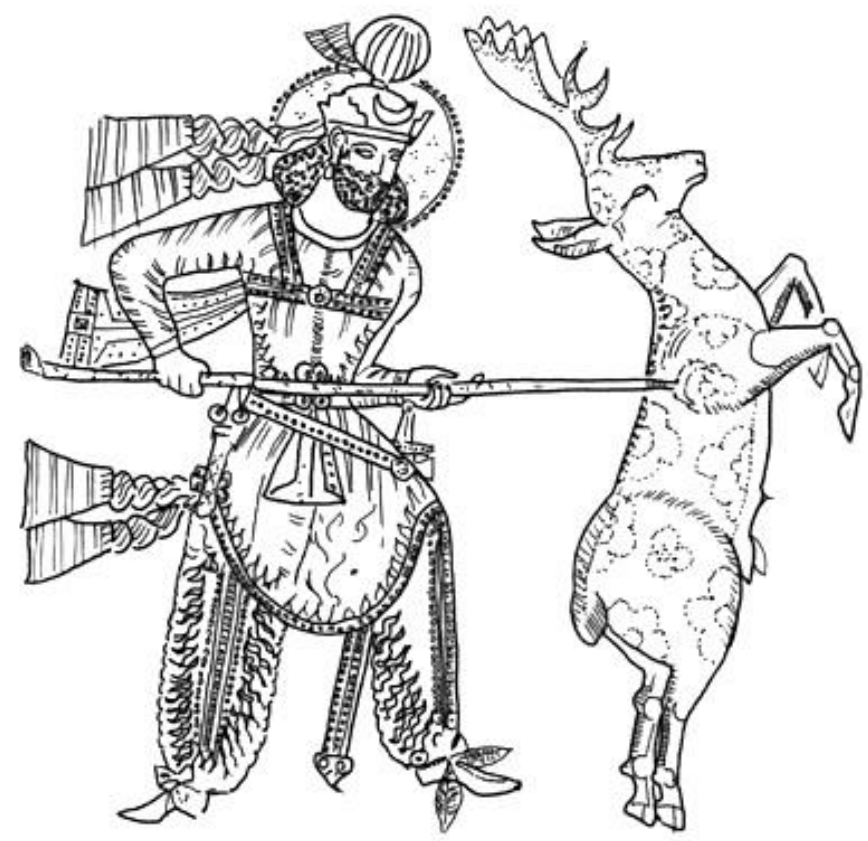

Fig. 4. Yazdagerd killing a stag from the plate from Mertopolitan Museum of Arts collection (drawing by Patryk Skupniewicz)

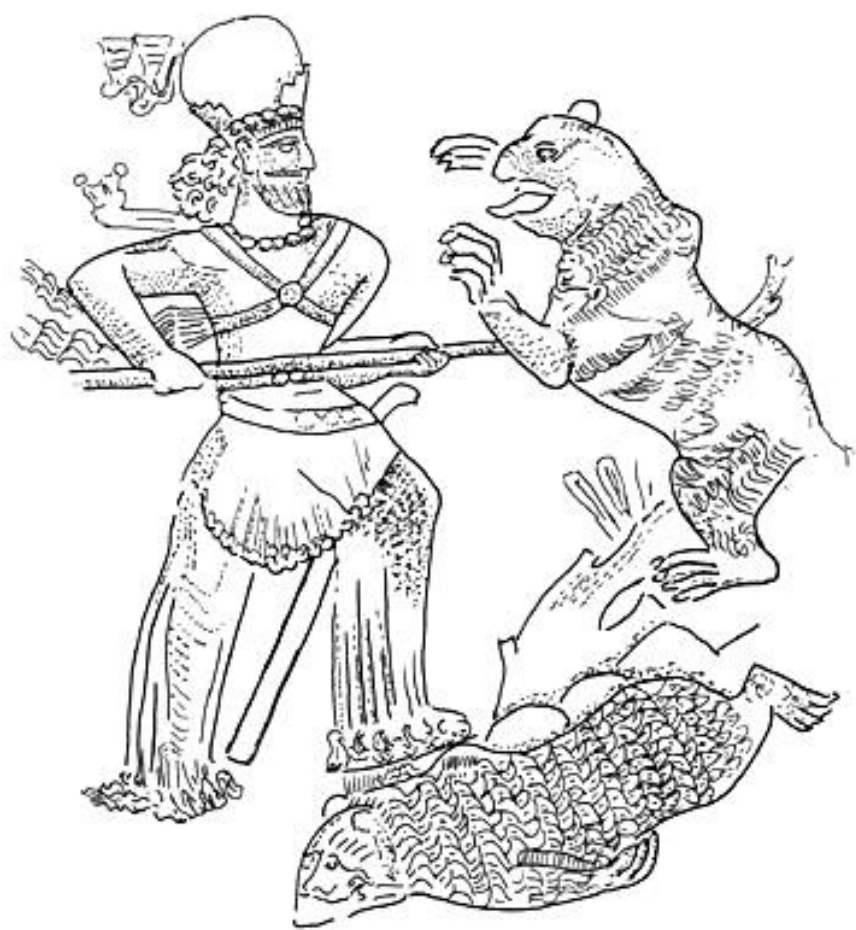

Fig. 5. Šāpūr II fighting bears from Shogakukan collection (drawing by Patryk Skupniewicz) 


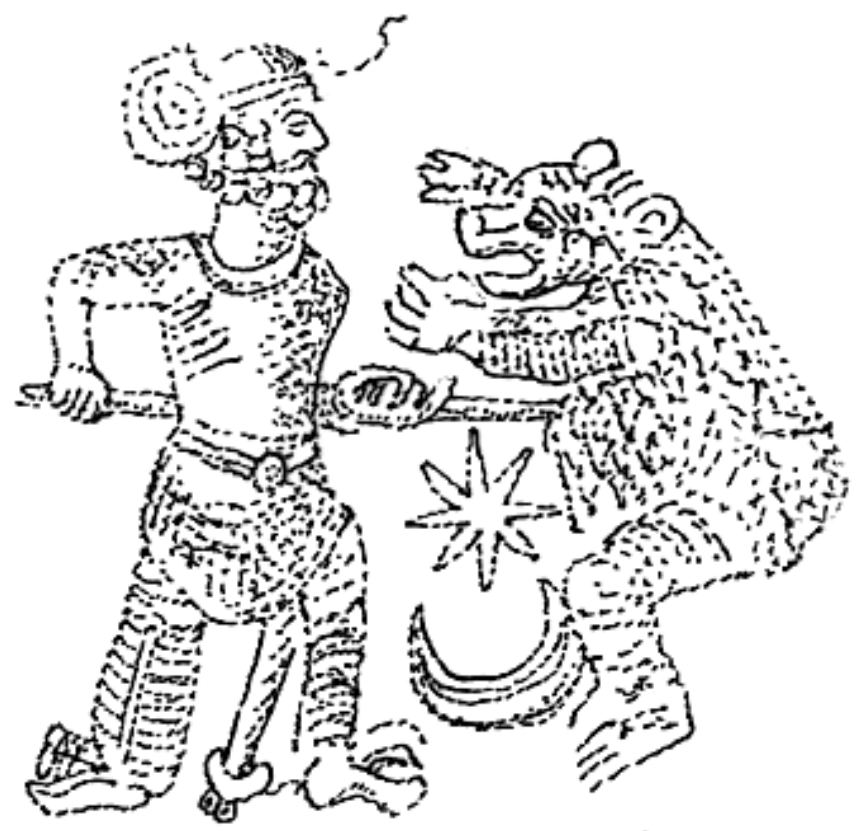

Fig. 6. Seal impression from M. Foroughi collection (drawing by Patryk Skupniewicz)

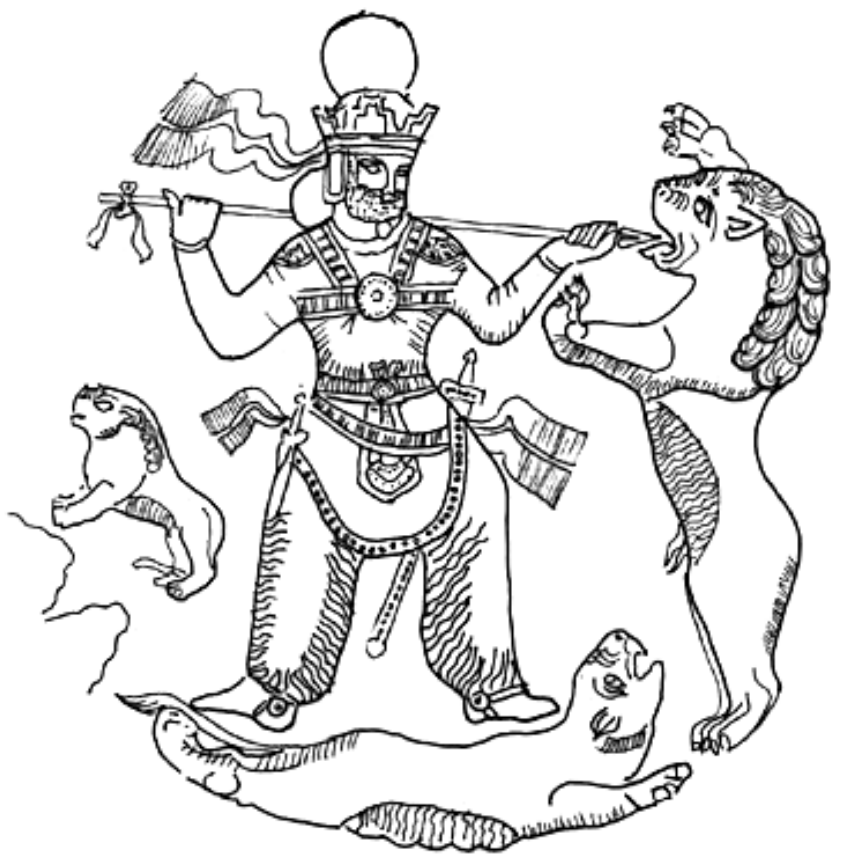

Fig. 7. Plate from Seattle Museum of Arts collection (drawing by Patryk Skupniewicz) 


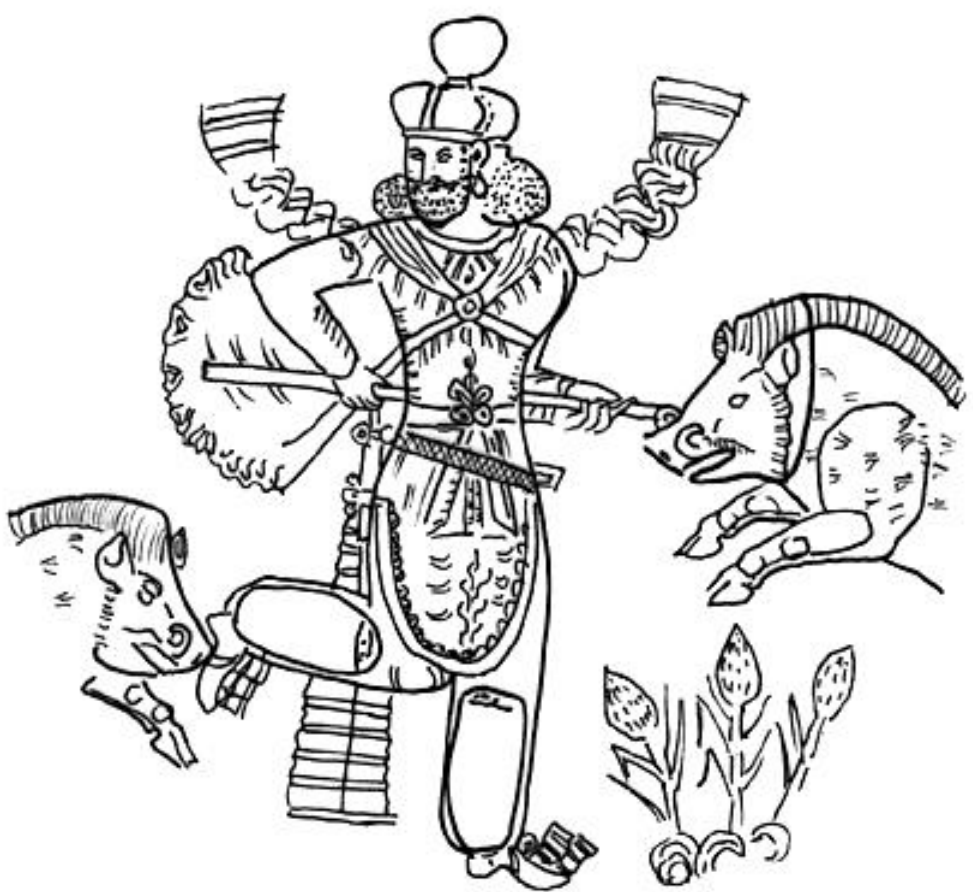

Fig. 8. Plate from Shelby and White collection (drawing by Patryk Skupniewicz)

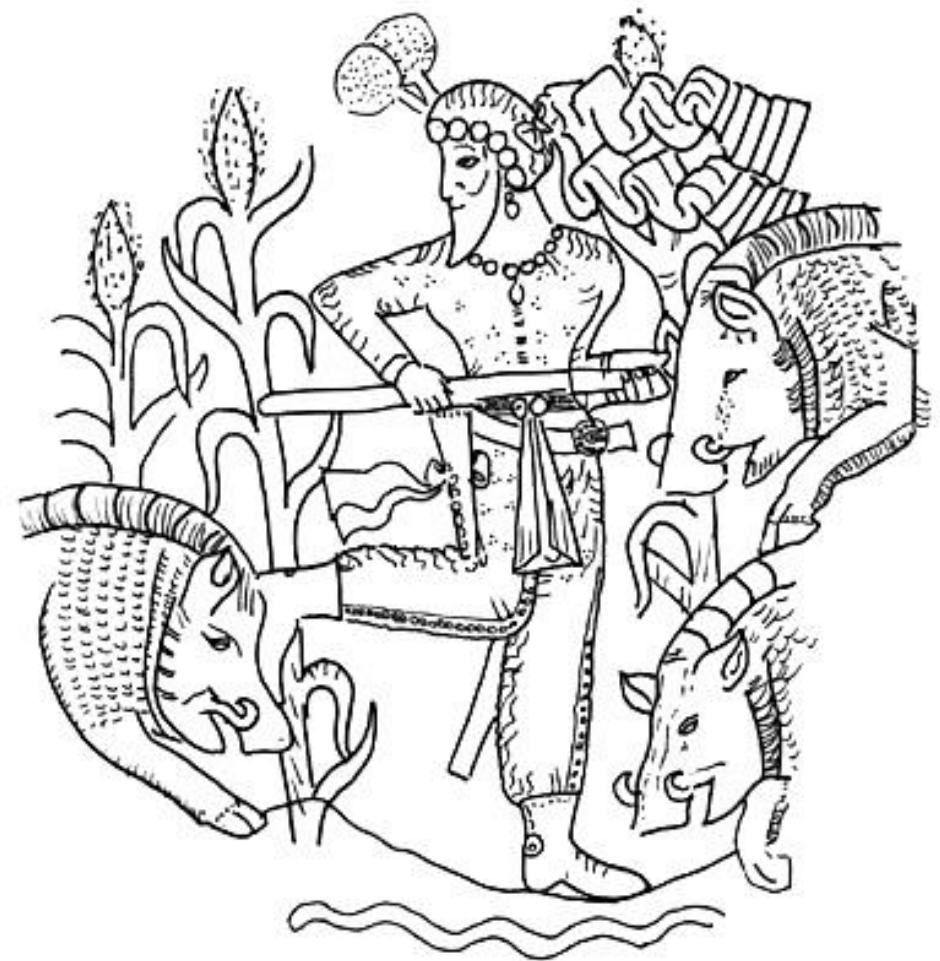

Fig. 9. Plate from the tomb of Feng Hetu (drawing by Patryk Skupniewicz) 
There are examples of lances being held with both hands diagonally downwards in depictions of the mounted boar hunts on the clasp from Saksankhur ${ }^{43}$, on post-Sasanian stucco from Chal-Tarkhan [Fig. 10] ${ }^{44}$ or one of the scenes on the bowl from British Museum attributed as Hephatlite ${ }^{45}$. All depict the prey in the form of protomes. The personage on the odd plate from Bastis collection [Fig. 11] also thrusts a boar with this lance placed diagonally however its shaft is carefully hidden behind the body of the hunter ${ }^{46}$. The last example of a rider performing downwards lance thrust with the shaft across the chest in Sasanian related toreutics is the depiction on Sanya Family plate [Fig. 12] with the personage riding a bull in flying gallop killing another bull in lower register ${ }^{47}$. Although the position of the central lancer holding a shaft diagonally, usually marking diagonal direction of entire composition seems to have some relation with boars, perhaps following a not preserved narrative. This type may have derived from the Achaemenid and post-Achaemenid Anatolian Çan sarcophagus hunting scene, stela from Çavuskoy, Greco-persian seal hunting scenes which include all main elements however showing shorter single-handed wielded lance. The plate form Burnes collection ${ }^{48}$, known only from the $19^{\text {th }}$ century drawings depicted a lion hunt with the lance held diagonally across the rider's chest and hitting the prey located diagonally alongside the rim of the plate, the type which might be associated with the earlier Achaemenid hunting and combat iconography.

The proportions of the personage do not match the proportions of the men in Sasanian art, his legs are too long in relation to torso. His tunic seems too short for Sasanian fashion and the almond shaped tassels hanging from the boots hardly find precedence in Sasanian iconography. If anything hangs from the ankles of the hunters, these are ribbons often with a supplementing bow tie. Only on the plate from Metropolitan Museum with Yazdegerd slaying a deer the ribbons are shaped into oval shapes, they are however much smaller than the ones on discussed plate and clearly identifies as ribbons by the bow. The type of the physiognomy, headgear and the coiffure are well attested in Sasanian sigillography, rock reliefs and toreutics. The type of the robe is also common however usually these long kaftans are not shown floating behind the personage but hanging freely alongside the body.

\footnotetext{
${ }^{43}$ SKUPNIEWICZ 2009: 58-59, Fig. 18; FRANCFORT 2002.

${ }^{44}$ SKUPNIEWICZ 2009: 59-60.

${ }^{45}$ HARPER, MEYERS 1981: 130-131, Fig. 44; NIKONOROV 1997; SKUPNIEWICZ 2009: 58-59, Fig. 17.

${ }^{46}$ GRABAR 1967: 50-52, Pl. 4; SKUPNIEWICZ 2009: 61-62, Fig. 26.

${ }^{47}$ BAULO 2002: 142-148; SKUPNIEWICZ 2009: 62, Fig. 27.

${ }^{48}$ HARPER, MEYERS 1981: 212, Pl. 11a \& 11b.
} 


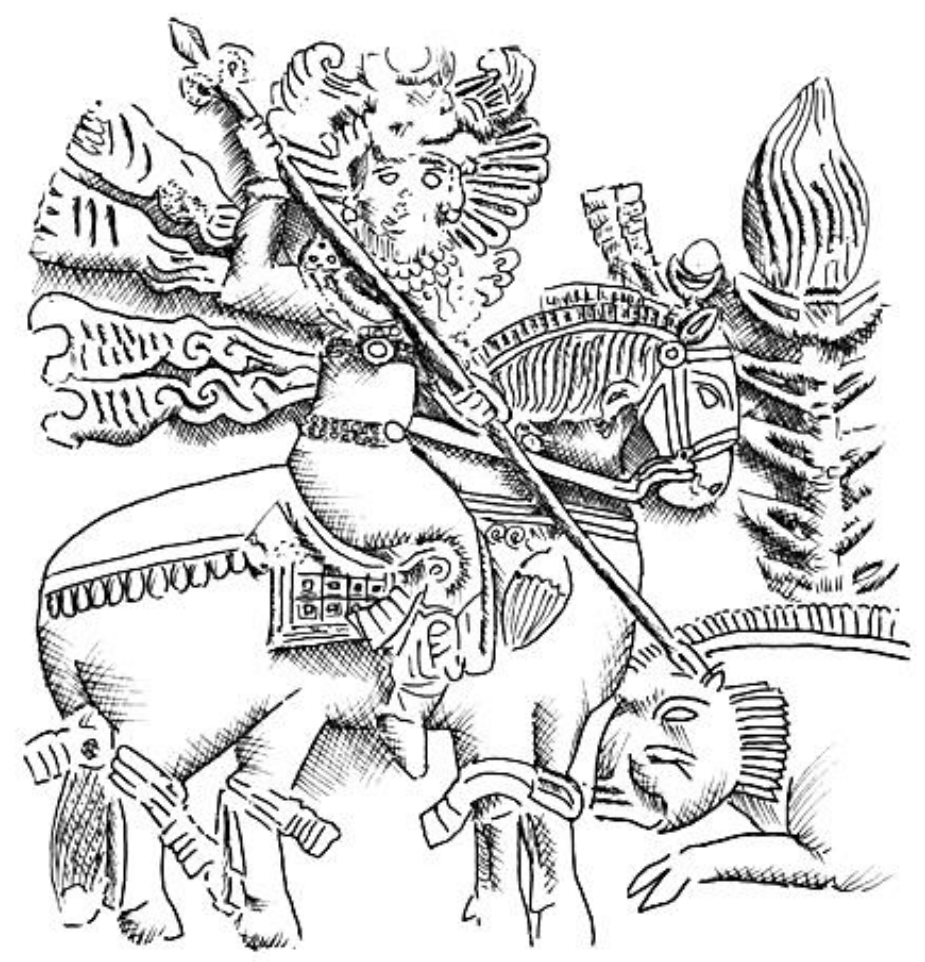

Fig. 10. Hunting scene from Chal Tarkhan stucco frieze (drawing by Patryk Skupniewicz)

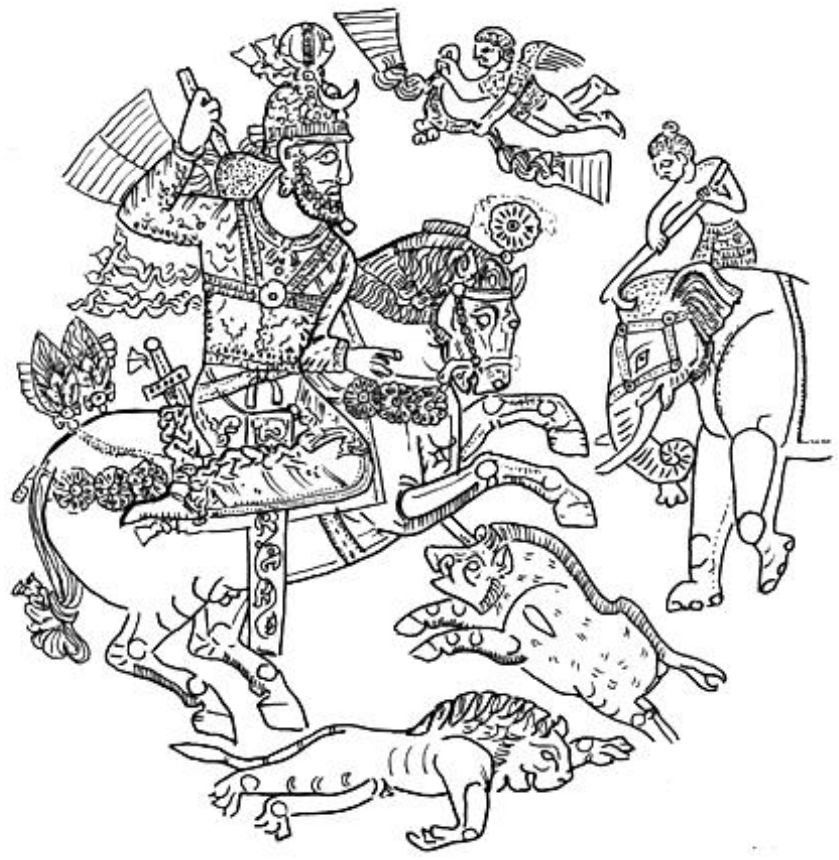

Fig. 11. Scene from Bastis collection plate (drawing by Patryk Skupniewicz) 


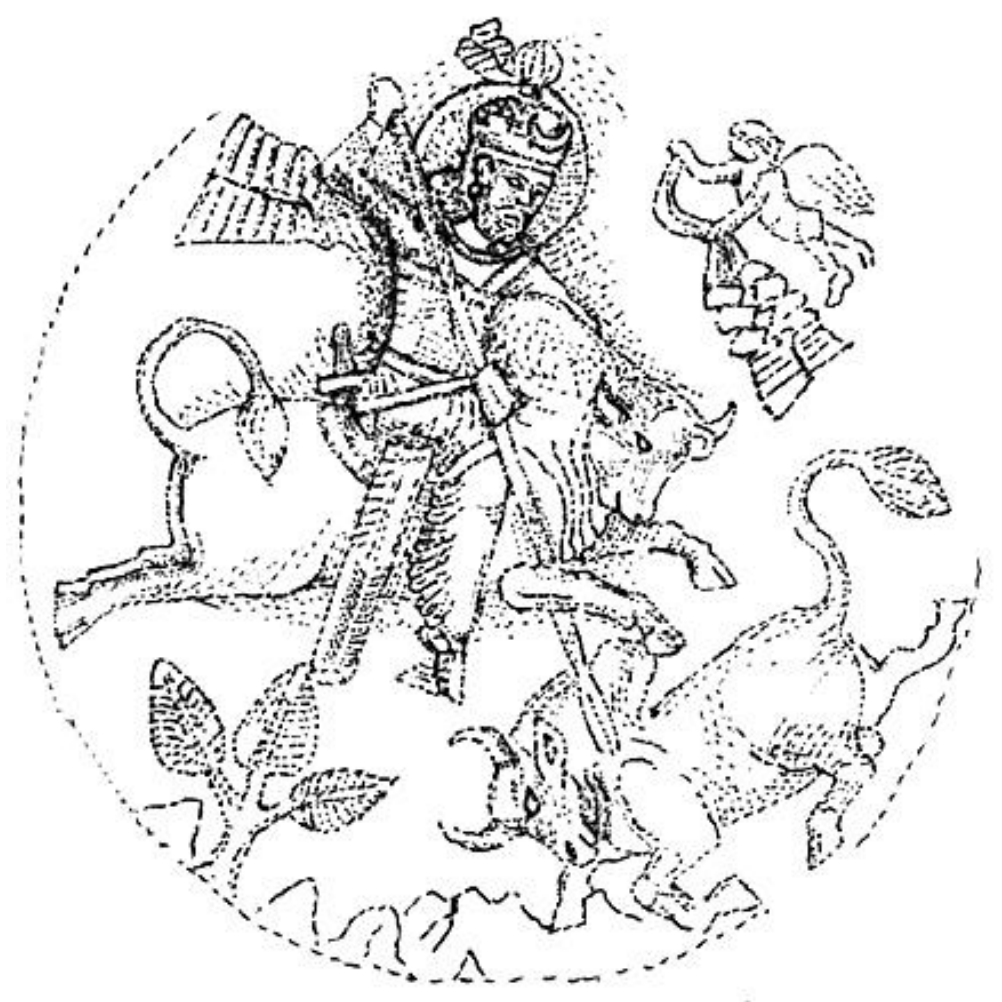

Fig. 12. Sanya Family plate (drawing by Patryk Skupniewicz)

Oblique, downwards position of the boar finds no clear precedence either. The boars are depicted either as protomes, or just parts popping out from the thicket, sometimes diminished to fit the field, or in whole, sometimes jumping towards the hunter. As said earlier - 'Parthian' plate from al-Șabāh Collection is another exception. The only representation of oblique stretched bodies of the boars is the dead prey on one of the panels in Țāq-e Bostān but than they are clearly separated from the heroic hunter. On one of the hunting scenes on the bowl from British Museum ${ }^{49}$ one of the boars is shown directed downwards with his body stretched parallel to another boar jumping upwards. Probably the only analogy of the formula applied in the central medallion of al-Șabāh plate would be the ivory plaque from Nimrud where the defeated griffon was placed diagonally with the head downwards. The difference is that on Nimrud plaque the direction of the victim emphasizes diagonal direction marked by the spear of the warrior so it works opposite than in al-Ṣabāh plate. Also, necessity to turn the prey's head towards the hunter which results with dynamic twist of the beast's neck in Nimrud plaque, in al-Ṣabāh ends in awkward combination of diagonal body and upwards direction of the mouth. The head of the boar with wide open mouth and huge low tooth is unparalleled in Sasanian art.

${ }^{49}$ SKUPNIEWICZ 2009: 59, Fig. 17. 


\section{Hunting scenes surrounding central medallion}

The hunters in a circle are an old motif in East Iran. It can be found on Bone plates from Orlat ${ }^{50}$, and as was said above on the bowl from Vereino in Hermitage Museum and on the bowl from British Museum. On Oxus disc, Vereino bowl and alȘabāh Collection plate there are three riders in each which might be accidental but also might refer to a lost narrative or mythical situation together with the bone plaque from Orlat with the hunting scene where three mounted hunters were also depicted.

However, fighting the life-threatening or powerful beasts and slaughtering numbers of prey seem two separate genres of the Sasanian iconography the division between them might have not been strict. On Hephtalite bowl from British Museum tiger, boar and lion hunts are represented together with mountain goat hunt. Also on the plaque from Takht-e Sanghin ${ }^{51}$ mounted hunt for small prey is accompanied with the scene of shooting a leopard. The difference between engagement in combat with a large, dangerous animal and spreading slaughter among the herds of herbivores might be a Western Iranian feature not cultivated in Eastern parts of Greater Iran or might simply come from the nature of majority of scenes restricted to single plate. This oddity of composition of the al-Șabāh plate has been discussed above.

The leopards on the al-Ṣabāh plate are shown in the unique, unknown otherwise way. The diagonally stretched beasts with the bodies crossing in an ' $\mathrm{X}$ ' shape are not surprising, they are present on the bowls from Vereino in Hermitage Museum and on from British Museum however the downwards direction of one of predators has no analogy. Just like in the case of the boar of the central scene, the beast depicted with the body turned down seems to deny heroic logic of the depiction where the hero faces the upright beast which is active, full of energy. True that the discussed leopard is dead but the X-shaped form of showing dead and alive beasts is totally new element in Sasanian visual language.

\section{Conclusions}

The plate from al-Șabāh collection is a unique, extraordinary piece. Although technically irreproachable, it contains several novelties in comparison to the known 'corpus' of Sasanian art:

$>$ The main hunt scene is placed in the medallion surrounded by the brim including other hunting scenes.

$\triangleright$ The sequence of the hunting scenes is placed inside of the vessel.

\footnotetext{
${ }^{50}$ ILYASOV 2003: Pl. VII.

${ }^{51}$ ILYASOV 2003: Pl. VI.
} 
$>$ The internal element - the central scene and external motif - the sequence of hunts was mixed up and placed together.

$>$ Central scene has no parallels in Sasanian iconography. It contains elements of several Near Eastern motifs.

$\Delta$ The leopards in X layout should have the heads up.

All these discrepancies are potentially enriching our knowledge of Sasanian art. They might become milestones in our vision of development of Sasanian formulae or the principles in which they were applied. With the proper archaeological context, the plate could add valuable data to the picture of aesthetics of Sasanian Empire and relations of arts of Eastern and Western Iran. With unknown provenance the questions raised speak against its genuineness at least until new, legitimate founds would confirm that the novelties are indeed set within aesthetics of the era. Also, the fact that two compositional/formulaic discrepancies occur on the vessels from the same collection and none can be provided with sound provenance may suggest either an unknown local tradition or certain preference of the manufacturer.

At the same time it must be reminded that the Sasanian silver plate discovered by the Czech expedition in Mes 'Aynak [Fig. 13] would result in similar objections unless originating from the legal excavations carried in accordance with academic criteria, or at least legal with the preserved place and context of finding ${ }^{52}$. The plate contains number of unorthodox features (two beasts attacking the protagonist, untypical sword and sheath, the treatment of the tigers, to name the most eye-catching ones) however instead of raising doubts towards its genuineness, it enriches the knowledge about Sasanian aesthetics, iconography and principles of visual constructions.

${ }^{52}$ MLEZIVA 2016. 


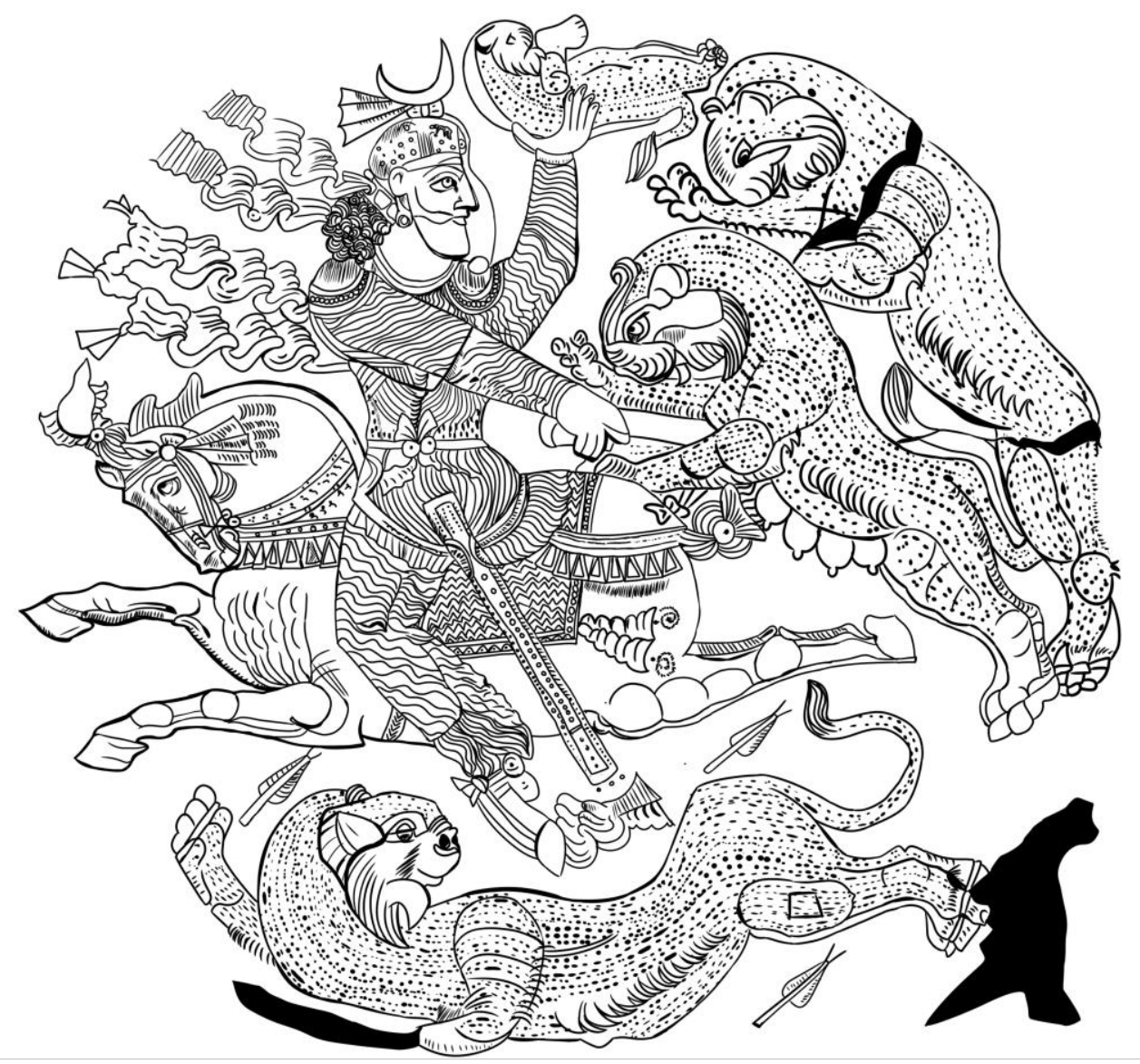

Fig. 13. Sasanian silver plate from Mes 'Aynak (drawing by Eleonora Skupniewicz)

\section{Bibliography}

BAULO A.V. (2002), 'A Sasanian silver plate from the Synya, Archaeology, Ethnology \& Anthropology of Eurasia 1, 142-148.

BOARDMAN J. (2000), Persia and the West, London.

CARTER M. (2015), Arts of the Hellenized East. Precious Metalwork and Gems of the Pre-Islamic Era, London.

CIAFALONI D., DELLA ROCA DE CANDAL G. (2011), 'Sasanian Traditions in Sogdian Paintings: Hunting and Fighting Scenes', Parthica 13, 111-128.

FRANCFORT H.P. (2002), 'Images du combat contre le sanglier en Asie centrale (3 ème au 1 er millénaire av. J.-C.)', Bulletin of the Asia Institute 16, 117-142.

FREEMAN D. (2013), (ed.), Splendors of the Ancient East, London.

GRABAR O. (1967), Sasanian Silver. Late Antique and Early Mediaeval Arts of Luxury From Iran. Michigan.

GRAY B. (1991), 'Post-Sasanian Metalwork', Bulletin of the Asia Institute 5, 59-63.

GUNTER A.C., JETT P. (1992), Ancient Iranian Metalwork in the Arthur M. Sackler Gallery and the Freer Gallery of Art, Washington D.C.

HARPER P.O. (1979), 'Thrones and Enthronement Scenes in Sasanian Art', Iran 17, 49-64. 
HARPER P.O. (1983), 'Sasanian Silver', in The Cambridge History of Iran 3(2), The Seleucid, Parthian and Sasanian Periods, Cambridge, ed. E. YARSHATER, Cambridge, 1113-1130.

HARPER P.O. (2000), 'Sasanian Silver Vessels: The Formation and Study of Early Museum Collections', in Mesopotamia and Iran in Parthian and Sasanian Periods: Rejection and Revival. C. 238 BC-AD 642, ed. J. CURTIS, London, 70-75.

HARPER P.O. (2006), In Search of a Cultural Identity. Monuments and Arti-facts of the Sasanian Near East. 3rd to 7th Century A. D., New York 2006.

HARPER P.O. (2008), Image and Identity: Art of the Early Sasanian Dynasty', in The Sasanian Era. Vol. III. The Idea of Iran, eds.V.S. CURTIS, S. STEWART, London and New York, 71-87.

HARPER P. O., MEYERS P. (1981), Silver Vessels of the Sasanian Period. Vol. I. Royal Imagery, New York.

HERRMANN G. (2017), Ancient Ivory. Masterpieces of the Assyrian Empire, London.

ILYASOV J. (2003), 'Covered Tile and “Flying” Tassels,' Iranica Antiqua 38, 259-325.

KARIMIAN H. (2008), Iranian Society in the Sasanian Period, in Current Research in Sasanian Archaeology, Art and History. Proceedings of a Conference held at Durham University, November 3rd and 4th, 2001, eds. D. KENNET, P. LUFT, Oxford, 99-107.

KOLESNIKOV A.I. (2012), Sasanidskiy Iran. Istoriya i kultura, St. Petersburg.

LUKONIN V.G. (1983), 'Political, Social and Administrative Institutions: Taxes and Trade', in The Cambridge History of Iran 3(2), The Seleucid, Parthian and Sasanian Periods, Cambridge, ed. E. YARSHATER, Cambridge, 681-746.

MARSCHAK B.I. (1986), Silberschätze des Orients. Metalkunst des 3.-13. Jahr-hunderts und ihre Kontinuität, Leipzig.

MARSHAK B.I. (1971), Sogdiiskoe serebro. Ocherki po vostochnoi torevtike, Moskva

MARSHAK B.I (2002), 'Pre-Islamic Painting of the Iranian Peoples and its Sources in Sculpture and Decorative Arts', in Peerless Images. Persian Painting and its Sources, eds. E. SIMS, B.I. MARSHAK, E. J. GRUBE, New Haven and London, 7-19.

MARSHAK B.I. (2017), Istoriya vostochnoy torevtiki III-XIII vv. i problemy kulturnoy preemstvennosti, Sankt Petersburg.

MARSHAK B.I., KHIKIS YA. B, (1969), 'Chilekskie Chashi', Trudy Gossudarsvennogo Ermitaža 10, $55-80$.

MLEZIVA J. (2016), 'Silver Vessels from Mes'Aynak', in Afghanistan. Rescued Treasures of Buddhism, L. STANČO, Prague, 99-105.

NIKONOROV V. (1997), The Armies of Bactria 700 BC-450 AD, vol. 2, Stockport.

OLBRYCHT M.J. (2010), 'Iran Starożytny', in: Historia Iranu, ed. A. KRASNOWOLSKA, Wrocław, 25-286.

ROSEN-AYALON M. (1991), 'A Non-Royal Hunter Vessel', Bulletin of the Asia Institute 5, 66-67.

RITTER N.C. (2010), Die altorientalischen Traditionen der sastnidischen Glyptik. Form-GebrauchIkonographie, Wien and Berlin.

SKJAERVØ P.O. (2013), 'The Inscription', in Splendors of the Ancient East. Antiquities from The alSabah Collection, M. CARTER, S. GOLDSTEIN, P.O. HARPER, T.S. KAWAMI, P. MEYERS, London, 299.

SKUPNIEWICZ P.N. (2009), 'Shafted Weapons of Sasanian Hunting Iconography', Fasciculi Archaeologiae Historicae 22, 49-64.

SKUPNIEWICZ P.N. (2015), 'Tabriz Museum Battle Dish. Formal Considerations', Metamorfozy Istorii 6, 180-211.

ŠLYAHOVA V.I. (1977), 'Serebranyi sosud iz s. Yuldus (Kurganskaya Oblast)', Sovetskaya Arheologiya 4, 288-292.

TREVER K.V., LUKONIN V.G. 1987, Sasanidskoe serebro. Sobranie Gosudarstvennogo Ermitaža. Hudožestvennaya kultura Irana III-VIII vekov, Moskva 